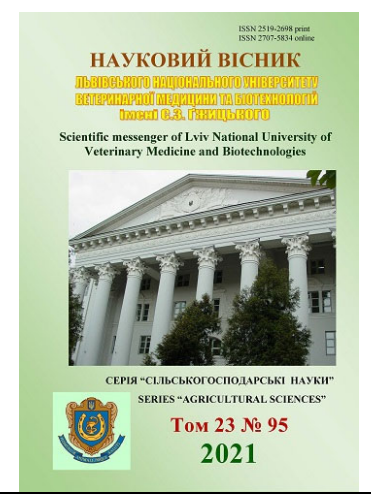

Науковий вісник Дьвівського національного університету ветеринарної медицини та біотехнологій імені С.3. Гжицького. Серія: Сільськогосподарські науки

\author{
Scientific Messenger of Lviv National University \\ of Veterinary Medicine and Biotechnologies. \\ Series: Agricultural sciences
}

doi: 10.32718/nvlvet-a9514

https://nvlvet.com.ua/index.php/agriculture

UDC 636.92:636.087.7

\title{
Fattening indicators of young rabbits when feeding Prebiolact-Kr
}

\author{
O. B. Tsyhanchuk
}

Vinnytsia National Agrarian University, Vinnytsia, Ukraine

Article info

Received 17.05.2021

Received in revised form 21.06.2021

Accepted 22.06.2021

Vinnytsia National Agrarian University, Soniachna Str.,3, Vinnytsia, 21000, Ukraine. Tel.: +38-098-004-27-64 E-mail:Shtenskal@uk.net
Tsyhanchuk, O. B. (2021). Fattening indicators of young rabbits when feeding Prebiolact-Kr. Scientific Messenger of Lviv National University of Veterinary Medicine and Biotechnologies. Series: Agricultural sciences, 23(95), 96-100. doi: 10.32718/nvlvet-a9514

Measures to increase production are used to address the issue of providing the population with food. During the peak of the industry (1975-1985), Ukraine annually produced 120-165 thousand tons of rabbit meat, 30-45 million skins, and its share in world rabbit production reached $8 \%$. In the national volume of meat production, the share of highly dietary rabbit accounted for 8-10\%. Rabbit breeding in Ukraine was a very lucrative industry, which employed more than 600 thousand rabbit breeders. However, in recent years, rabbit breeding has declined due to the lack of modern scientific developments on the issues of complete feeding, rabbit keeping technology, low level of breeding and veterinary support. The development of the industry and the lack of coordinating bodies, both in the center and on the ground, are holding back. At present, the rabbit population of Ukraine is $97-98 \%$ concentrated in individual farms and is 1.2-1.3 million breeding and repair livestock, and the rest in farms and breeding entities of various forms of ownership and management. According to the results of state certification, the breeding base of the industry in Ukraine today consists of 1 breeding plant and 7 breeding breeders of rabbit breeds. For feeding young rabbits used complete ration granular feed, the structure of which had different prebiotic content: I control group - the drug was not received, 2 experimental - 1.5, 3-2.0, 4-2.5 g/goal. per day. The studies were conducted on four groups of young rabbits, selected on the principle of groups of analogues, 25 heads in each. Thus, the total amount of feed increased from $80 \mathrm{~g} / \mathrm{goal}$. per day (35-41 days), up to $100 \mathrm{~g}$ (42-48 days), $120 \mathrm{~g}$ (49-55 days), up to $140 \mathrm{~g}$ (56-62 days), up to $160 \mathrm{~g}$ (63-69 days) up to $180 \mathrm{~g}$ (70-76 days). Feeding of young rabbits when reared for meat Prebiolact-Kr in animals of the second group at $43.1 \mathrm{~g}$, the third $44.6 \mathrm{~g}$ and $45.0 \mathrm{~g}$. The use of Prebiolact-Kr in the feeding of young rabbits when fed meat contributes to an increase in fattening performance, which may be the basis for the practical application of this supplement. Perebiolakt-KR showed the best results in feeding fattening and repair young animals at a dose of $2.0 \mathrm{~g} / \mathrm{goal}$ per day.

Key words: live weight, rabbit, meat qualities, bacterial preparation, average daily gains.

\section{Відгодівельні показники молодняку кролів при згодовуванні Пребіолакт- Кр}

О. Б. Циганчук

Вінницький національний аграрний університет, м. Вінниця, Україна

\footnotetext{
До заходів щчодо збільшення виробництва вдаються задля розв'язання питання по забезпеченню населення продуктами харчування. У роки найвищого розквіту галузі (1975-1985 роки) в Україні щорічно вироблялось 120-165 тис. тонн м'яса кролів, 3045 млн шкурок, а ї̈ частка у світовому виробництві кролятини досягала 8 \%. У загальнодержавному обсязі виробництва м'яса на частку високо-дієтичної кролятини припадало 8-10\%. Кролівництво в Україні було досить прибутковою галуззю, в якій було зайнято понад 600 тис. кролівників. Проте, у останні роки кролівництво занепало через відсутність сучасних наукових розробок $з$ питань повноцінної годівлі, технології утримання кролів, низький рівень ведення племінної роботи і ветеринарного забезпечення. Стримує розвиток галузі і відсутність координаційних органів, як у центрі, так і на місиях. На даний час поголів'я кролів Украӥни на 97-98 \% сконщентровано у індивідуальних селянських господарствах і становить 1,2-1,3 млн маточного і ремонтного поголів'я, а решта у фермерських господарствах та племінних суб'єктах різних форм власності та господарювання. За результатами дер-
} 
жавної атестаиї, племінну базу галузі в Украӥні на сьогодні складають 1 племінний завод та 7 плем-репродукторів з розведення порід кролів. Для годівлі молодняку кролів використовували повнораціонні гранульовані комбікорми, у структурі яких був різний вміст пребіотику: І контрольна група - препарат не отримувала, 2 дослідна - 1,5, 3 - 2,0, 4 - 2,5 г/гол. за добу. Дослідження були проведені на чотирьох групах молодняку кролів, відібраних за принципом груп аналогів, по 25 голів у кожній. Так, загальна кількість корму збільшувалась від 80 г/гол. за добу (35-41 діб), до 100 г (42-48 діб), 120 г (49-55 діб), до 140 г (56-62 діб), до 160 г (6369 діб) до 180 г (70-76 діб). Згодовування молодняку кролів при вирощуванні на м ясо Пребіолакт-Кр у тварин другої групи на 43, 1 г , третьої 44,6 г та 45,0 г. Використання Пребіолакт-Кр в годівлі молодняку кролів при вигодовуванні на м'ясо сприяє збільшенню відгодівельних показників, щзо може бути основою для практичного застосування цієї добавки. Найкращі показники в годівлі відгодівельного та ремонтного молодняку показав Перебіолакт-КР в дозі 2.0 г/гол за добу.

Ключові слова: жива маса, кролятина, м'ясні якості, бактеріальний препарат, середньодобові прирости.

\section{Вступ}

Доведено, що в результаті інтенсивної відгодівлі, порівняно з помірною, підвищується середньодобовий приріст маси, скорочується період годівлі та знижуються витрати кормів на одиницю продукції.

Нині кролівництво в нашій країні незаслужено призабуте, та воно, поза сумнівом, залишається однією 3 найперспективніших галузей українського тваринництва.

У XXI ст. почався інтенсивний розвиток кролівництва завдяки сучасним досягненням селекції щодо виведення скороспілих порід, типів, ліній м'ясного напрямку, а також науковим розробкам з питань годівлі, технології утримання і вирощування. Подальшому розвитку галузі сприяють виняткові біологічні та господарсько-корисні особливості кролів, серед яких найціннішими є: високоплідність, скороспілість, оплата корму та ефективне використання поживних речовин раціону (Abdel-Wareth \& Metwally, 2020; Bojko et al., 2020; Boiko et al., 2020; 2021).

Перетравність корму пов'язана 3 особливостями травлення і залежить від виду, віку і стану тварини, а також від властивостей кормів та техніки годівлі (Nemirovskaja \& Jacuta, 1994).

Сьогодні існує ряд кормових компонентів, які стимулюють продуктивність i ріст тварин (Darmohray, 2012; Darmohray et al., 2017; 2019; Lesyk et al., 2020). Одним із них $є$ пребіотичні препарати, які позитивно впливають на посилення імунітету, зміцнення здоров'я, та збільшення продуктивності різних видів сільськогосподарських тварин і звірів (Izmailova \& Havryliuk, 2015). Чисельні дані свідчать про ефективність впливу пребіотичних препаратів на молодняк.

В результаті досліджень вчених виявлено позитивний вплив пребіотика на ріст свиней, перетравність поживних речовин (Tsyhanchuk, 2019).
Доведено, що в результаті інтенсивної відгодівлі, порівняно 3 помірною, підвищується середньодобовий приріст маси, скорочується період годівлі та знижуються витрати кормів на одиницю продукції.

Сьогодні існує цілий ряд кормових компонентів, які стимулюють продуктивність і ріст тварин. Одними 3 них $є$ пробіотичні препарати, які позитивно впливають на посилення імунітету, зміцнення здоров'я та збільшення продуктивності різних видів сільськогосподарських тварин. Чисельні дані свідчать про ефективність впливу пробіотичних препаратів на молодняк.

Сучасний споживчий ринок перенасичений різноманітними захисними ветеринарними препаратами та кормовими добавками, що створює нагальну проблему щодо визначення їх ефективності з урахуванням вимог безпеки препаратів для тварин, людей та довкілля.

Метою досліду було встановити оптимальну дозу препарату до повнораціонного гранульованого комбікорму для відгодівельного та ремонтного молодняку кролів.

\section{Матеріал і методи досліджень}

Аналізуються показники продуктивності молодняку кролів м'ясного гібриду HYPLUS селекції компанії Grimaud Freres Selection, який був створений у Франції шляхом схрещування двох ліній кролів: батьківської PS 39 та материнської PS 19.

Зрівняльний період тривав протягом семи днів і збігався 3 молочним періодом кролів. Тварини другої групи до основного гранульованого комбікорму отримували Пребіолакт-Кр в дозі 1,5 г/гол. за добу, третьої $-2,0$ г/гол. за добу, четвертої - 2,5 г/гол. за добу.

Для проведення досліду за принципом аналогів було відібрано чотири групи тварин по двадцять п'ять голів у кожній. Перша група була контрольною. Схему досліду наведено в таблиці 1.

\section{Таблиця 1}

Схема проведення дослідів на тваринах

\begin{tabular}{|c|c|c|c|}
\hline \multirow{2}{*}{ Групи } & \multirow{2}{*}{$\begin{array}{c}\text { Кількість } \\
\text { тварин, гол }\end{array}$} & \multicolumn{2}{|c|}{ Характеристика годівлі тварин за періодами } \\
\hline & & зрівняльний & основний \\
\hline \multicolumn{4}{|c|}{ Відгодівельний молодняк } \\
\hline 1 - контрольна & 25 & OP & OP \\
\hline 2 - дослідна & 25 & OP & ОР+ “Пребіолакт-Кр” 1,5 г на голову за добу \\
\hline 3 - дослідна & 25 & OP & ОР+ “Пребіолакт-Кр" 2,0 г на голову за добу \\
\hline 4 - дослідна & 25 & OP & ОР+ "Пребіолакт-Кр" 2,5 г на голову за добу \\
\hline
\end{tabular}


Дослідження були проведені в умовах фізіологічного двору. Кожну тварину утримували індивідуально, в спеціально обладнаних клітках. Кролям контрольної групи згодовувався основний раціон. Тварини другої групи до повноцінного гранульованого комбікорму отримували Пребіолакт-Кр у кількості 1,5 г, третьої - 2 г, четвертої - 2,5 г на голову за добу.

Годівля тварин та облік спожитих кормів були індивідуальними. Протягом облікового періоду відбирались зразки калу та сечі. Дослідження відібраних зразків проводились за методиками зоотехнічного аналізу (Kozyr', 2002). Біометрична обробка отриманих даних була проведена за М. О. Плохінським (Plohinskij, 1969).

\section{Результати та їх обговорення}

Дослідження показали, що використання в годівлі кролів препарату Пребіолакт-КР в дозі 2,0 г на голову за добу має позитивний продуктивний ефект (табл. 2). Порівняно кращі результати були при споживанні препарату Пребіолакт-КР в дозі 2,5 г на голову за добу. Так, середньодобові прирости молодняку кролів третьої групи збільшувалися проти контрольного значення на 2,3 г.

У тварин третьої групи, що одержували Пребіолакт-Кр в дозі 2,5 г на голову за добу різниця за відгодівельними показникам порівняно $з$ контрольним значенням була також вірогідною, але рівень їх був дещо нижчим щодо другої та третьої групи.

\section{Таблиця 2}

Середньодобові прирости молодняку кролів, г $(\mathrm{M} \pm \mathrm{m}, \mathrm{n}=25)$

\begin{tabular}{ccccc}
\hline \multirow{2}{*}{ Віковий період, діб } & \multicolumn{4}{c}{ Група } \\
\cline { 2 - 5 } & $\begin{array}{c}1 \\
\text { (контрольна) }\end{array}$ & $\begin{array}{c}2 \\
\text { (дослідна) }\end{array}$ & $\begin{array}{c}3 \\
\text { (дослідна) }\end{array}$ & $\begin{array}{c}4 \\
\text { (дослідна) }\end{array}$ \\
\hline $35-41$ & $43,3 \pm 0,32$ & $43,7 \pm 0,23$ & $43,2 \pm 0,29$ & $43,5 \pm 0,19$ \\
$42-48$ & $48,6 \pm 0,27$ & $49,1 \pm 0,30$ & $49,2 \pm 0,21$ & $49,0 \pm 0,18$ \\
$49-55$ & $49,8 \pm 0,30$ & $50,8 \pm 0,88$ & $53,0 \pm 0,92^{*}$ & $54,2 \pm 1,11^{* *}$ \\
$56-62$ & $42,4 \pm 0,18$ & $44,3 \pm 0,74^{*}$ & $50,1 \pm 0,88^{* * *}$ & $51,2 \pm 0,75^{* * *}$ \\
$63-69$ & $36,2 \pm 0,22$ & $36,2 \pm 0,62$ & $37,9 \pm 0,54^{*}$ & $38,0 \pm 0,66^{*}$ \\
$70-76$ & $33,7 \pm 0,24$ & $34,5 \pm 0,35$ & $34,2 \pm 0,32$ & $34,1 \pm 0,28$ \\
3а весь період досліду & $42,3 \pm 0,29$ & $43,1 \pm 0,21$ & $44,6 \pm 0,31^{* * *}$ & $45,0 \pm 0,34^{* * *}$ \\
\hline
\end{tabular}

Молодняк кролів отримував Пребіолакт-Кр в раціоні групи тварин: контрольна препарат не отримувала, перша група - 1,5 г на голову за добу, друга група $-2,0$ г на голову за добу, третя $-2,5$ г на голову за добу. Дані про вміст поживних речовин в комбікормі та загалом за періодами росту свідчать про те, що молодняк кролів був достатньо забезпечений всіма поживними та біологічно активними речовинами. Це сприяло збільшенню середньодобових приростів за періодами росту у тварин другої групи на 43,1 г, 44,6 г та 45,0 г відповідно.
Найкращий показник показали тварини другої групи у віковому періоді 49-55 діб, він становив $50,8 \pm 0,88$; третьої - у віковому періоді 49-55, що становив $53,0 \pm 0,92$; четвертої групи - у віковому періоді з 56-62 діб, який становив 54,2 $\pm 1,11$.

Про характер годівлі відгодівельного молодняку за періодами росту, зазначеними в схемі досліду табл. 1, свідчать дані табл. 3. Так, загальна кількість корму збільшувалась від 80 г/гол. за добу (35-41 доба), до 100 г (42-48 діб), 120 г (49-55 діб), до 140 г (56-62 доби), до 160 г (63-69 діб) до 180 г (70-76 діб), про що свідчать дані таблиці 3.

\section{Таблиця 3}

Середньодобове споживання комбікорму відгодівельним молодняком, г/гол.

\begin{tabular}{ccccc}
\hline \multirow{2}{*}{ Віковий період, діб } & \multicolumn{5}{c}{ Група } \\
\cline { 2 - 5 } & $\begin{array}{c}1 \\
\text { (контрольна) }\end{array}$ & $\begin{array}{c}2 \\
\text { (дослідна) }\end{array}$ & $\begin{array}{c}3 \\
\text { (дослідна) }\end{array}$ & $\begin{array}{c}4 \\
\text { (дослідна) }\end{array}$ \\
\hline $35-41$ & 80 & 80 & 80 & 80 \\
$42-48$ & 100 & 100 & 100 & 100 \\
$49-55$ & 120 & 120 & 120 & 120 \\
$56-62$ & 140 & 140 & 140 & 160 \\
$63-69$ & 160 & 160 & 160 & 180 \\
$70-76$ & 180 & 180 & 780 & 780 \\
\hline
\end{tabular}

Таким чином, використання препарату Пребіолакт-Кр в годівлі молодняку кролів при вигодовуванні на м'ясо сприяє збільшенню відгодівельних показників, що може бути основою для практичного застосування цієї добавки.
Споживання корму відгодівельним молодняком кролів залежно від вікового періоду було 80 г на голову, і з кожним періодом збільшували на 20 г. Тваринами кожної групи за весь період досліду було спожито по 780 г/гол. за добу, всіма групами за весь дослідний період було спожито 78 кг комбікорму. 
Таблиця 4

Середньодобові прирости ремонтного молодняку кролів, г $(\mathrm{M} \pm \mathrm{m}, \mathrm{n}=25)$

\begin{tabular}{ccccc}
\hline Віковий період, діб & 1 (контрольна) & 2 (дослідна) & 3 (дослідна) & 4 (дослідна) \\
\hline $35-41$ & $39,5 \pm 0,4$ & $39,1 \pm 0,6$ & $39,9 \pm 0,3$ & $39,1 \pm 0,5$ \\
$42-48$ & $44,4 \pm 0,4$ & $44,9 \pm 0,3$ & $45,6 \pm 0,4$ т & $45,8 \pm 0,5$ \\
$49-55$ & $45,8 \pm 0,4$ & $46,2 \pm 0,5$ & $47,2 \pm 0,4^{*}$ & $47,5 \pm 0,4^{*}$ \\
$56-62$ & $42,5 \pm 0,3$ & $43,5 \pm 0,4$ т & $43,9 \pm 0,4^{*}$ & $44,1 \pm 0,4^{*}$ \\
$63-69$ & $36,2 \pm 0,3$ & $37,1 \pm 0,2^{*}$ & $37,8 \pm 0,3^{* *}$ & $38,4 \pm 0,3^{* * *}$ \\
$70-76$ & $33,2 \pm 0,3$ & $34,6 \pm 0,5^{*}$ & $35,8 \pm 0,4^{* * *}$ & $35,6 \pm 0,4^{* *}$ \\
$77-83$ & $19,3 \pm 0,9$ & $22,6 \pm 0,5^{*}$ & $23,4 \pm 0,6^{* *}$ & $24,1 \pm 0,7^{* *}$ \\
$84-90$ & $14,8 \pm 0,8$ & $15,4 \pm 0,6$ & $17,5 \pm 0,5^{*}$ & $17,8 \pm 0,6^{*}$ \\
$91-97$ & $15,3 \pm 0,9$ & $15,8 \pm 0,5$ & $16,8 \pm 0,5$ & $17,4 \pm 0,4$ т \\
$98-104$ & $14,2 \pm 0,9$ & $15,2 \pm 0,6$ & $16,2 \pm 0,5$ т & $16,5 \pm 0,6 \mathrm{~T}$ \\
$105-111$ & $14,8 \pm 0,9$ & $15,0 \pm 0,5$ & $16,5 \pm 0,4$ & $16,4 \pm 0,5$ \\
$112-118$ & $14,4 \pm 0,8$ & $15,8 \pm 0,5$ & $16,2 \pm 0,3$ т & $16,5 \pm 0,4^{*}$ \\
$119-125$ & $15,7 \pm 0,9$ & $15,9 \pm 0,4$ & $16,5 \pm 0,3$ & $16,5 \pm 0,3$ \\
$126-132$ & $15,2 \pm 0,8$ & $15,8 \pm 0,6$ & $16,3 \pm 0,4$ & $16,1 \pm 0,5$ \\
$133-139$ & $15,8 \pm 0,9$ & $15,3 \pm 0,5$ & $16,0 \pm 0,3$ & $16,4 \pm 0,4$ \\
$140-146$ & $15,0 \pm 0,9$ & $15,7 \pm 0,4$ & $16,4 \pm 0,4$ & $16,5 \pm 0,4$ \\
$147-153$ & $15,5 \pm 0,9$ & $15,0 \pm 0,5$ & $16,5 \pm 0,4$ & $16,0 \pm 0,5$ \\
$154-160$ & $15,5 \pm 0,9$ & $15,8 \pm 0,6$ & $16,0 \pm 0,3$ & $15,7 \pm 0,4$ \\
3а весь період досліду & 22,9 & 24,4 & 25,3 & 25,4 \\
\hline
\end{tabular}

Про характер годівлі ремонтного молодняку кролів за періодами росту, зазначеними в схемі досліду табл. 1, свідчать дані табл. 4. Середньодобові прирости ремонтного молодняку кролів порівняно 3 контрольною групою: у другій групі , яка отримувала Пребіолакт-КР в дозі 1,5 г/гол. за добу, середнє значення середньодобових приростів - 24,4 г, третя група отримувала Пребіолакт-КР 2,0 г/гол. за добу і середнє значення по групі становить 25,3 г/гол. за добу, четверта група отримувала Пребіолакт-КР в дозі 2,5 г/гол. за добу і середнє значення по групі становило 25,4 г/гол. за добу. Тому вищий показник був у групі, яка отримувала препарат у дозі 2,0 г/гол за добу, порівняно з контрольною - на 2,4 г.

Найкращі результати з середньодобових приростів були у контрольній групі, другій, третій та в четвертій групах у віковому періоді 49-55 діб і становили 45,8 \pm

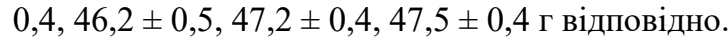

\section{Висновки}

1. Так, загальна кількість корму збільшувалась від 80 г/гол. за добу (35-41 доба), до 100 г (42-48 діб), 120 г (49-55діб), до 140 г (56-62 доби), до 160 г (6369 діб), до 180 г (70-76 діб).

2. Використання препарату Пребіолакт-Кр в годівлі молодняку кролів при вигодовуванні на м'ясо сприяє збільшенню відгодівельних показників, що може бути основою для практичного застосування цієї добавки.

3. Найкращі показники в годівлі відгодівельного та ремонтного молодняку показав Перебіолакт-КР в дозі 2,0 г/гол. за добу.

Перспективи подальших досліджень. Подальші дослідження будуть зосередженні на вивченні впливу різних доз Пребіолакт-Кр на показники забою молодняку кролів.

\section{References}

Abdel-Wareth, A. A. A., \& Metwally, A. E. (2020). Productive and Physiological Response of Male Rabbits to Dietary Supplementation with Thyme Essential Oil. Animals, 10(10), 18-44. doi: 10.3390/ani10101844.

Boiko, O. V., Honchar, O. F., Lesyk, Y. V., Kovalchuk, I. I., \& Gutyj, B. V. (2020). Effect of zinc nanoaquacitrate on the biochemical and productive parameters of the organism of rabbits. Regulatory Mechanisms in Biosystems, 11(2), 243-248. doi:10.15421/022036.

Boiko, O. V., Honchar, O. F., Lesyk, Y. V., Kovalchuk, I. I., Gutyj, B. V., \& Dychok-Niedzielska, A. Z. (2021). Effect of consumption of I, Se, S and nanoaquacitrates on hematological and biochemical parameters of the organism of rabbits. Regulatory Mechanisms in Biosystems, 12(2), 335-340. doi: 10.15421/022145.

Bojko, O. V., Darmohray, L. M., Luchyn, I. S., Honchar, O. F., \& Gutyj, B. V. (2020). Specific activity of Sr90 and Cs-137 in rabbits of various genotypes. Ukrainian Journal of Ecology, 10(2), 165-169. doi: $10.15421 / 202080$.

Darmohray, L. M. (2012). Biotransformatsiia pozhyvnykh rechovyn netradytsiinykh kormiv u orhanizmi tvaryn. Monohrafiia. Lviv (in Ukrainian).

Darmohray, L. M., Luchyn, I. S., \& Gutyj, B. V. (2017). Influence of feeding management on productive indicators of rabbits for intensive growing technology. Scientific Messenger LNUVMB, 19(79), 38-43. doi: $10.15421 /$ nvlvet7908.

Darmohray, L. M., Luchyn, I. S., Gutyj, B. V., Golovach, P. I., Paskevych, G. A., \& Zhelavskyi M. M. (2019). Trace elements transformation in young rabbit muscles. Ukrainian Journal of Ecology, 9(4), 616-621. doi: 10.15421/2019_798.

Izmailova, N. O., \& Havryliuk, O. I. (2015). Efektyvnist vykorystannia probiotyka pry vidluchenni kroleniat. Visnyk Sum-skoho natsionalnoho ahrarnoho universytetu, 6(128), 114-116 (in Ukrainian). 
Kozyr', V. S. (2002). Prakticheskie metodiki issledovanij v zhivotnovodstve: uchebnoe posobie, 79-97 (in Russian).

Lesyk, Y., Ivanytska, A., Kovalchuk, I., Monastyrska, S., Hoivanovych, N., Gutyj, B., Zhelavskyi, M., Hulai, O., Midyk, S., Yakubchak, O., \& Poltavchenko, T. (2020) Hematological parameters and content of lipids in tissues of the organism of rabbit saccording to the silic on connection. Ukrainian Journal of Ecology, 10(1), 15-22 doi: 10.15421/2020_3.
Nemirovskaja, L. N., \& Jacuta, L. V. (1994). Vlijanie molochnokislyh bakterij na gistologicheskuju strukturu organov pishhevaritel'nogo trakta teljat. Mikrobiologicheskij zhurnal, 56(2), 88 (in Russian).

Plohinskij, N. A. (1969). Prakticheskoe rukovodstvo po biometrii dlja zootehnikov. M.: Kolos (in Russian).

Tsyhanchuk, O. B. (2019). Peretravnist pozhyvnykh rechovyn kormu za dii prebiotyka $\mathrm{v}$ ratsioni remontnoho molodniaku kroliv. Ahrarna nauka ta kharchovi tekhnolohii, 3(106), 156-161 (in Ukrainian). 